\title{
Mapping of natural populations of Euterpe oleracea Mart., structure and estimates of fruit production at Araguari River, Eastern Amazon
}

\author{
Mapeamento de populações naturais de Euterpe oleracea Mart., \\ estrutura e estimativas da produção de frutos no rio Araguari, Amazônia \\ oriental
}

\author{
Adriano Castelo dos Santos ${ }^{1}$ (D), João da Luz Freitas ${ }^{1}$ (D), Francisco de Oliveira Cruz Junior ${ }^{1}$ (D) \\ ${ }^{1}$ Instituto de Pesquisas Científicas e Tecnológicas do Estado do Amapá - IEPA, Macapá, AP, Brasil
}

How to cite: Santos, A. C., Freitas, J. L., \& Cruz Junior, F. O. (2021). Mapping of natural populations of Euterpe oleracea Mart., structure and estimates of fruit production at Araguari River, Eastern Amazon. Scientia Forestalis, 49(132), e3714. https://doi.org/10.18671/scifor.v49n132.13

\begin{abstract}
This study aimed to identify the occurrence of natural populations of açaí palms in the low-land forest at Araguari River; to map the native açaí palm areas; to assess the structure of the açaí areas; to quantify the clumps of açaí palm trees and to estimate the fruit production. The study was conducted in the Araguari River Valley, state of Amapá, eastern Amazon, Brazil, covering the municipalities of Ferreira Gomes and Cutias, over a $68 \mathrm{~km}$ extension. For the sampling of the açaí palm area, we established 89 $(10 \mathrm{~m} \times 20 \mathrm{~m}$ ) sampling plots, totaling a sample area of $1.78 \mathrm{ha}$. To measure the height and diameter of the palm trees, only palms with circumference at breast height $(\mathrm{CBH}) \geq 20 \mathrm{~cm}$ were considered. The quantification of açaí fruits production was obtained through information provided by the owners who commercialize the fruit in the region. It was found that the açaí palm tree is present in the entire plantphysiognomy of the studied area. The high density and the high number of palms per clump shows that the açaí area is native and not managed. The average height of $16 \mathrm{~m}$ of the açaí palm indicates a need to reduce the dominant height of the palm trees in these places. The low estimate of açaí palm tree fruit production led us to conclude that the native açaí palm area of the Araguari River valley are of low production, although the areas are densely populated with açaí palm trees.
\end{abstract}

Keywords: Flooded forest; Food security; Income; Non-timber forest product.

\section{Resumo}

Este trabalho teve como objetivo identificar a ocorrência de populações naturais de açaizeiro (Euterpe oleracea Mart.) na floresta de várzea do rio Araguari, mapear os açaizais nativos, avaliar a estrutura dos açaizais, quantificar as touceiras de açaí e estimar a produção de frutos. O estudo foi realizado no Vale do Rio Araguari, Amapá, Brasil, abrangendo os municípios de Ferreira Gomes e Cutias, em uma extensão de 68 km. Para a amostragem da área, foram alocadas 89 parcelas retangulares de $10 \mathrm{~m} \times 20 \mathrm{~m}$, totalizando uma área amostral de 1,78 ha. Para mensurar a altura e o diâmetro das palmeiras, considerou-se apenas palmeiras com circunferência à altura do peito (CAP) $\geq 20$ $\mathrm{cm}$. A quantificação da produção do fruto do açaí foi obtida por meio de informações fornecidas pelos proprietários que comercializam o fruto na região. O açaizeiro está fortemente presente em toda a fitofisionomia da área estudada. A elevada densidade e número de palmeiras por touceira mostra que a área é nativa e não manejada. A altura média de $16 \mathrm{~m}$ das palmeiras de açaí indica a necessidade de reduzir a altura dominante dos açaizeiros nestes locais. A baixa estimativa da produção de frutos do açaizeiro corrobora para inferir que a área de açaizais nativos do Vale do rio Araguari apresenta baixa produção, embora as áreas sejam bastante adensadas.

Palavras-chave: Floresta inundada; Segurança alimentar; Renda; Produto florestal não madeireiro.

Financial support: Fundação de Amparo à Pesquisa do Estado do Amapá (FAPEAP), Chamada Pública 004/2017/FAPEAP - Memo n 003/2018 CCT/FAPEAP. Conflict of interest: Nothing to declare.

Corresponding author: adrianocasteloeng@gmail.com

Received: 14 May 2021.

Accepted: 30 August 2021.

Editor: Mauro Valdir Schumacher.

(c) This is an Open Access article distributed under the terms of the Creative Commons Attribution License, which permits unrestricted use, istribution, and reproduction in any medium, provided the original work is properly cited. 


\section{INTRODUCTION}

Açaí palms stand out in the Amazon lowland forests and their exploration is one of the most traditional activities developed by the riverside peoples of the Amazon estuary, which are always done in a family production system (Carvalho, 2018). Fruits of the açaí palm have been explored by riverside communities in the Amazon for millennia, especially as basic food and for medicinal and commercial uses (Freitas et al., 2015; Paniagua-Zambrana et al., 2017).

Euterpe oleracea Mart. (açaí palm tree), Magnoliophyta: family Arecaceae, is a species native to the Amazon River basin, grows in groups of 20 stipes that together can produce 120 $\mathrm{kg}$ of fruit per year or even more under management systems (Oliveira \& Schwartz, 2018). It is characterized by being a fast-growing palm, with the tallest stems reaching 20 to 25 meters. The root system is called a pneumatophore which allows it to adapt to seasonal floods and its flowers are unisexual grouped in composite panicles, from yellow-brown to purple in color (Amsellem-Laufer, 2015).

Recently açaí has become popular abroad as food and as a food ingredient, with nutritional and economic importance (for example, for export), mainly for its content in bioactive molecules that benefit human health (Menna, 2014). Açaí fruits are rich in anthocyanin antioxidants (Cordeiro et al., 2018; Wycoff et al., 2015).

Açaí palm tree is one of the most productive palm trees in the Amazon estuary ecosystem, and can provide wood for the construction of rural houses and fences for animal confinement, straw for coverings, seed for handicrafts, coloring and as pig feed, being a source of food and income (Quaresma \& Cunha, 2012). The importance of palm trees in rainforests is evident in cities and rural communities, where their ethno-botanical and economic uses reflect an entrenched local knowledge, which is still poorly understood elsewhere (Balslev et al., 2016).

This palm tree aroused great commercial interest due to its prospects of application in the food industries, combined with the large quantities existing in the Amazon region and the relative ease of extraction (Miranda et al., 2012). Recently, a study on agricultural practices and the trajectories of production systems in the states of Pará and Amapá showed a strong and rapid increase in the extraction of açaí in the household economy, when compared to other agricultural and mining products (Cialdella \& Navegantes Alves, 2014).

Recently some studies on the açaí palm were carried out in areas of the Amazon estuary (Cruz Junior, 2016) and in grottoes (Queiroz et al., 2015), however, research in the Araguari River valley region is non-existent, mainly with regard to the real potential of this species in the production of fruits and in the generation of income and food subsistence of riverside dwellers.

Araguari River Valley region has three hydroelectric plants installed along the river, which strongly affect the food security of local communities (Silva et al., 2018). In this sense of searching for new alternatives, açaí contributes to the economy and food security of local communities, being essential to know the potential of fruit production and identifying management approaches that support biodiversity and the ecosystem processes that support production in açaí palm areas (Campbell et al., 2018; Mendonça \& Del Bianchi, 2014).

Given the above, our aim was to identify natural populations of Euterpe oleracea Mart. in the Araguari River Valley; map the native açaí palm areas; assess the structure of the açaí palm areas; quantify the clumps of açaí palm trees and estimate fruit production. Our hypothesis is that $E$. oleracea has a high potential of productive individuals (adult palm trees) when compared to other plant-physiognomies, since it is adapted to floodplain forests.

\section{MATERIAL AND METHODS}

\section{Study area}

This study was conducted in the Araguari River Valley, State of Amapá, Brazil, over a $68 \mathrm{~km}$ stretch, departing from Ferreira Gomes to the head office of the municipality of Cutias, a stretch called the Lower Araguari River (Figure 1). The two municipalities are located in the 
mid-west region of Amapá, respectively, with Ferreira Gomes at the geographic coordinates $\mathrm{N} 00^{\circ} 51.38$ 'and $\mathrm{W} 051^{\circ} 11.74$ ' and Cutias at N $01^{\circ} 0.76$ 'and W $050^{\circ} 48.66$ '.

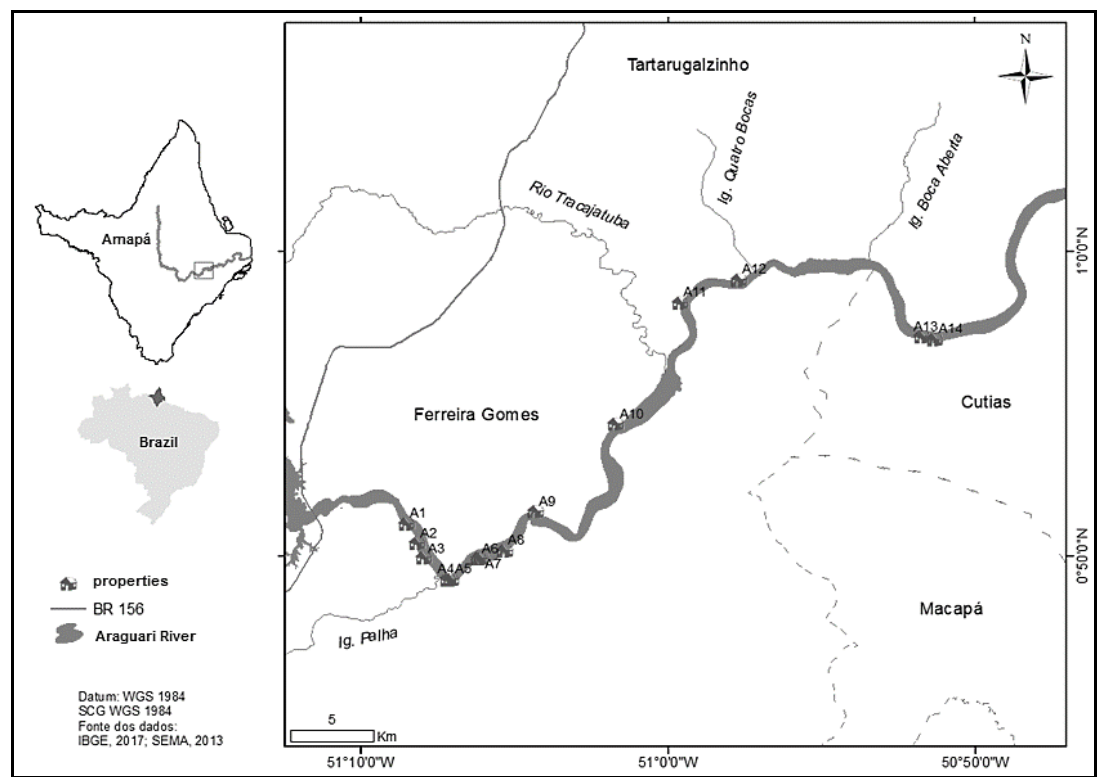

Figure 1. Location of the study area in the Araguari River region, Eastern Amazon.

The hydrographic basin of the Araguari River is the largest in Amapá, with approximately $42,000 \mathrm{~km}^{2}$, occupying approximately one third of the total area of the state, with $300 \mathrm{~km}$ in length, from the source to the estuary in the Atlantic Ocean (Eletronorte, 1999). The region's vegetation is composed of upland, lowland, igapó forests and natural fields. In the floodplain areas, natural populations of açaí palms stand out, well adapted to the conditions of high temperature and rainfall in the region. The region's climate is tropical rainy type Am, with annual precipitation above 3,300 $\mathrm{mm}$, according to the Köppen classification (Alvares et al., 2013), with maximum temperatures of $32.6^{\circ} \mathrm{C}$ and minimum of $20^{\circ} \mathrm{C}$.

\section{Data collection}

We identified 14 properties with native açaí palm areas, randomly distributed, as well as the location of the main rivers and streams of the studied perimeter. E. oleracea strongly composes the plant physiognomy of the studied area, however for this research; the properties were sampled according to criteria such as presence of açaí palm groups, permission to install the plots, collection of qualitative and quantitative data and geographical coordinates of the palm clumps.

We determined 89 rectangular plots of $10 \mathrm{~m} \times 20 \mathrm{~m}$ (0.02 hectare) in a systematic way, equidistant $25 \mathrm{~m}$ in 14 properties, totaling a sample area of 1.78 hectares. Plots were established within each of the properties (equidistant $5 \mathrm{~m}$ from each other) and had their vertices geo-referenced, as well as the entire palm clumps contained in it.

To measure the variables height $(\mathrm{m})$ and diameter $(\mathrm{cm})$, only stipes (individuals) with circumference at breast height $(\mathrm{CBH}) \geq 20 \mathrm{~cm}$ were considered. To indicate the potential of açaí palms in the studied region, a field form was prepared containing: the composition of the clump at the time of the inventory (young, adult palm and regeneration); and the dendrometric variables: height of the palm and $\mathrm{CBH}$.

Composition of the açaí clumps obeyed the following classification: adult individuals which had already started the fruiting phase; young individuals established in the clump and with height greater than $2 \mathrm{~m}$, but did not start the fruiting phase; and regeneration: seedling in the establishment phase with height less than 2 m, adapted from Queiroz et al. (2007). 
The quantification of fruit production $(\mathrm{kg}$ ) was obtained through information provided by the owners who sell the fruit in the region, with an estimated 26.8 bags $(50 \mathrm{~kg})$ per hectare on average. The spreadsheet was based on the following variables: harvest area per hectare; average productive palm trees per hectare; average of cans of fruit per palm/harvest; harvest cost per can and average selling price (bag of $50 \mathrm{~kg}$, in $\mathrm{R} \$$ ). The calculation of fruit production per hectare was based on the following expression, adapted from Wadt et al. (2004):

$F P=$ Npal $x$ Ncan

FP = Fruit production (per hectare/harvest)

$\mathrm{Npal}=$ number of adult palms per hectare

Ncan $=$ number of fruit cans per adult palm

The variable Can/hectare was converted to bag/ha, and the value obtained was divided by 4 , considering the ratio of 4 cans to 1 bag of açaí palm tree fruit.

\section{Data analysis}

To calculate the sampling intensity, simple random sampling estimators were used, based on the variable "number of clumps per plot". Sampling was considered sufficient at 99\% probability, admitting an error of $\pm 15 \%$ (admissible error) according to Soares et al. (2012).

Occurrence map of native açaí palm areas was made with the aid of the software TrackMaker-13.9 and ArcGIS-10.8.1. The plant-sociological variables obtained in the FITOPAC-2.1 software were absolute density, total basal area, absolute dominance, total volume, average diameter, average height and spatial distribution. Graphs were prepared using the statistical software R ( $R$ Development Core Team, 2020). Data were tested for normality and homoscedasticity as assumptions required for analysis of variance (ANOVA). For this, the Kolmogorov-Smirnov (Conover, 1971) and Levene (Brown \& Forsythe, 1974) tests were used, respectively (both at the $5 \%$ significance level).

Clump components (adults, young and regeneration) were compared using the KruskalWallis test, at 5\% probability (Dodge, 2008).

\section{RESULTS AND DISCUSSION}

\section{Occurrence of açai palm areas in the Araguari River}

The açaí palm tree is present across the plant physiognomy of the studied area, except pasture areas, very common in the region. The sampled area of 1.78 ha (89 plots) represents a total area equivalent to 10,600 ha; the part hatched on the map (Figure 2).

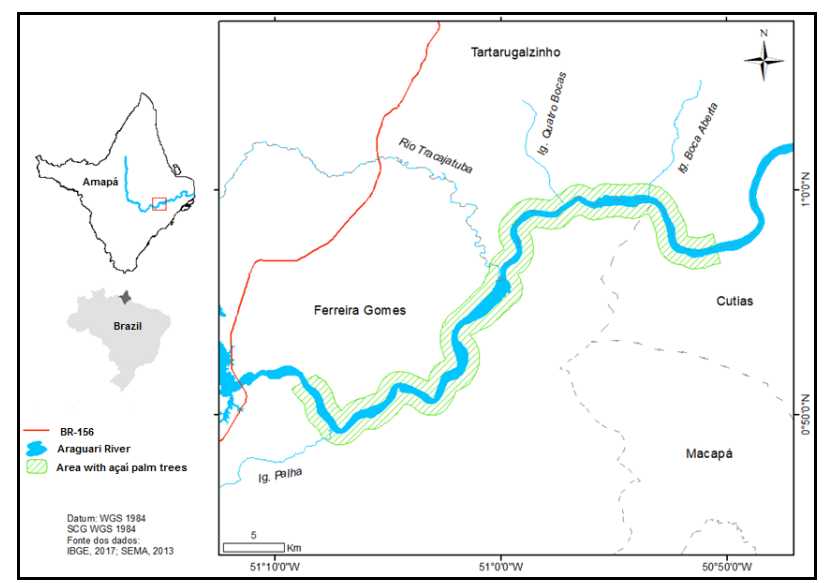

Figure 2. Total area considered as having potential for açaí palms in the Araguari river valley. Source: Forest management laboratory (2019). 
According to studies by Boaventura \& Narita (1974), the studied area has an evolutionary connection with the fluvial processes at estuary of the Amazon River, being classified as riverine-lacustrine Plains. River plains are surfaces of river accumulation, subject to periodic flooding with constant deposition of sediments (Instituto Brasileiro de Geografia e Estatística, 2004). Besides, the stretch comprised by the Lower Araguari River is subject to the daily influence of the tides across the Atlantic Ocean (Cunha et al., 2014).

The tropical climate, hydromorphic soils of good fertility and the regime of flood and ebb tides of the river that floods the forest at various times of the year, make the floodplain environment create a special, highly dynamic condition. The trees on these recent sediments do not escape from falling and the open clearings allow seed germination (Queiroz et al., 2007). Such conditions are conducive to the occurrence and establishment of palm trees, especially the species Euterpe oleracea (Azevedo, 2010; Wittmann et al., 2013).

A total of 1,075 açaí palm tree clumps were identified, which were measured and georeferenced within each $20 \mathrm{~m} \times 10 \mathrm{~m}$ sample plot, as seen in the example of area 5 in plot 1 (Figure 3).

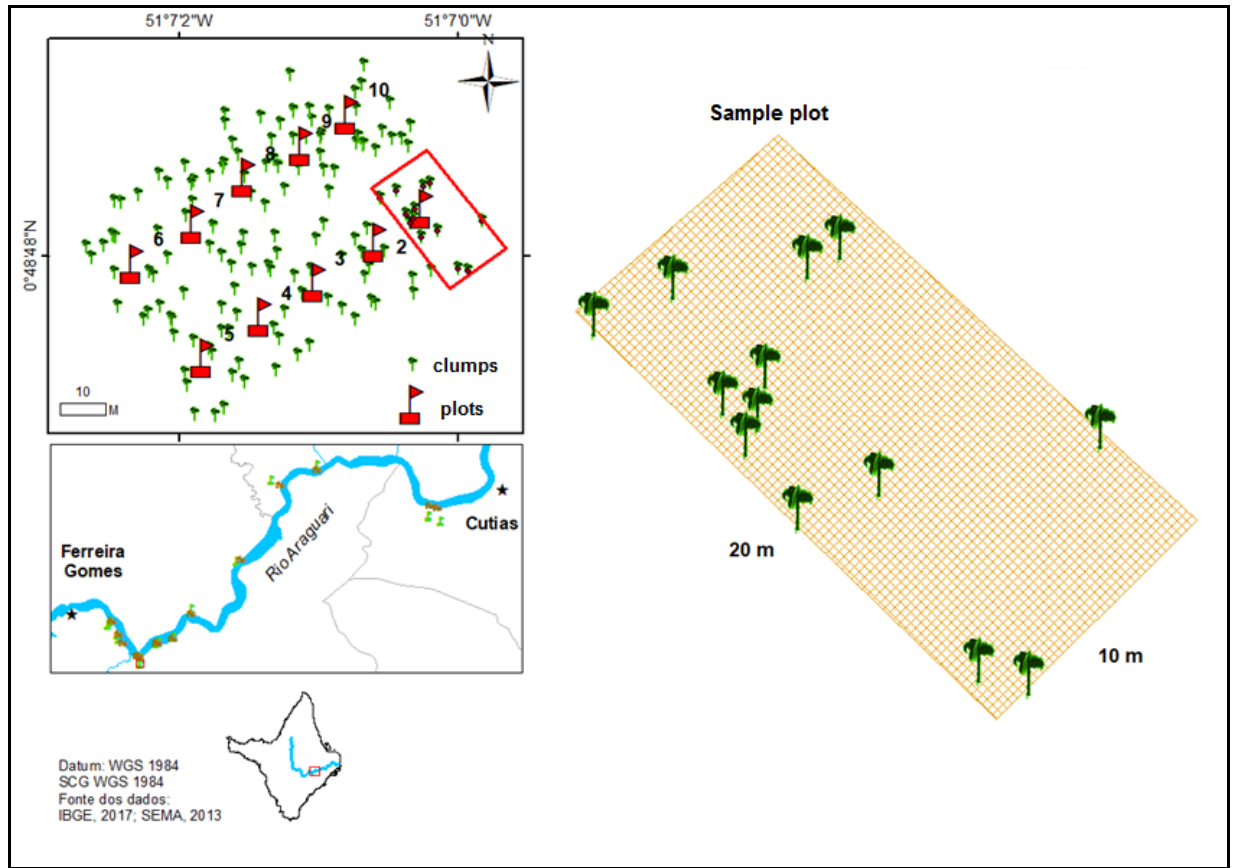

Figure 3. Arrangement of plots and clumps in an area with potential for açaí palm tree.

This specific survey of natural populations of E. oleracea is unprecedented in the region and stands in contrast to the little information available in the literature about the occurrence of this species, for example environmental studies of pre-installation of hydroelectric plants in the region (Ferreira Gomes, 2013; Ecotumucumaque, 2013) which underestimated the occurrence and potential of the species in the Araguari Valley. However, according to recent studies in the area (see Santos et al. (2015) and Freitas et al. (2020) for further details) local populations already indicated the use of products from this species, either for family consumption or commercialization of surplus fruit production.

\section{Horizontal and vertical structure}

Sampling of 89 plots was considered sufficient at 99\% probability, requiring 76 plots to guarantee the error of $\pm 15 \%$ (allowable error for the total area considered). The absolute sampling error was 1.68 clumps/plot or $13.74 \%$. The confidence interval for the number of clumps per hectare, at $99 \%$ probability, was $604.5 \pm 83.7$ clumps ha ${ }^{-1}$. 
A total of 4,077 açaí palms ( 1,075 clumps mapped) with $\mathrm{CBH} \geq 20 \mathrm{~cm}$ were counted in 89 sample plots of $200 \mathrm{~m}^{2}$ each, which make up the structural analysis of the native açaí palm areas (Table 1).

Table 1. Structural parameters of native açaí palm areas in the Araguari River.

\begin{tabular}{cc} 
Parameters & Values \\
\hline Absolute density & 2,290 \\
Total Basal Area & 33.84 \\
Absolute Dominance & 19.01 \\
Total volume & 634.09 \\
Average diameter & 10.02 \\
Average height & 16.19 \\
Spatial distribution & aggregated
\end{tabular}

* Absolute density (ind. ha-1); Total basal area $\left(\mathrm{m}^{2}\right)$; Absolute dominance $\left(\mathrm{m}^{2} \mathrm{ha}^{-1}\right)$

The studied population had a high absolute density $(2,290$ ind. ha-1) of açaí palms and a high absolute dominance of individuals in the evaluated area $\left(19.01 \mathrm{~m}^{2} \mathrm{ha}^{-1}\right)$.

On the island of Combu, eastern Amazon, the species E. oleracea also showed a high density of individuals, which were sampled in 0.5 hectares of lowland forest, totaling 2,597 palm trees (Maués et al., 2011). At the mouth of the Amazon River, in Amapá, Queiroz \& Machado (2008) also identified a high density of $E$. oleracea along the sampling units, showing good adaptability to the environment.

In a floodplain forest ( 2 ha of sample area) in the eastern Amazon, Almeida \& Jardim (2011) measured palm trees with $\mathrm{DBH} \geq 10 \mathrm{~cm}$ and reported that $E$. oleracea stood out in all plant sociological parameters, reaching 2,106 açaí palms. In the flooded forest in the Amazon, Lau \& Jardim (2013) evaluated $2.75 \mathrm{ha}$, all palm trees $\mathrm{CBH} \geq 10$, reported that E. oleracea stood out in relation to the other species in number of individuals, relative density, relative dominance and importance value.

In the eastern Amazon, Santos et al. (2018) analyzed high and low floodplain environments and obtained estimates for high floodplain of 457.03 ind. ha ${ }^{-1}$ and in the low floodplain of 467.44 ind. ha-1 ${ }^{-1}$, values for the density of individuals with $\mathrm{DBH} \geq 15 \mathrm{~cm}$.

These density values (cited above) contrast, for example, with data obtained in the Amazon River Delta around Belém (Pará), where the density of clumps per hectare varied between 20 and 210 clumps, an average of $78.3 \pm 59.4$ clumps ha $^{-1}$ (Freitas et al., 2015). This confirms the great potential of palm trees and the high density of E. oleracea in the Araguari Valley.

Regarding the distribution pattern, the species E. oleracea generally presents an aggregate spatial pattern, which is the most frequent among tropical palms (Cappelatti \& Schmitt, 2015). Thus, the aggregation of the species allows its permanent exploitation, as long as it is rationally managed to produce fruits and palm hearts.

As for the basal area of açaí palm areas, Santos et al. (2018) obtained results for dominance that varied from $0.23 \mathrm{~m}^{2} \mathrm{ha}^{-1}$ (in high floodplain) and dominance of $0.25 \mathrm{~m}^{2} \mathrm{ha}^{-1}$, in low floodplain, values much lower than the value observed at the Araguari River, which was $19.01 \mathrm{~m}^{2} \mathrm{ha}^{-1}$. This is evidence once again of the high density and increase in biomass that these açaí palm areas provide in the studied area.

The 4,077 inventoried individuals were measured from the diameter at breast height $(\mathrm{DBH} \geq 6.36 \mathrm{~cm})$, with an average diameter of $10.02 \mathrm{~cm}$. The individuals were distributed in diametric classes following the method of Sturges (1926) (Figure 4). 


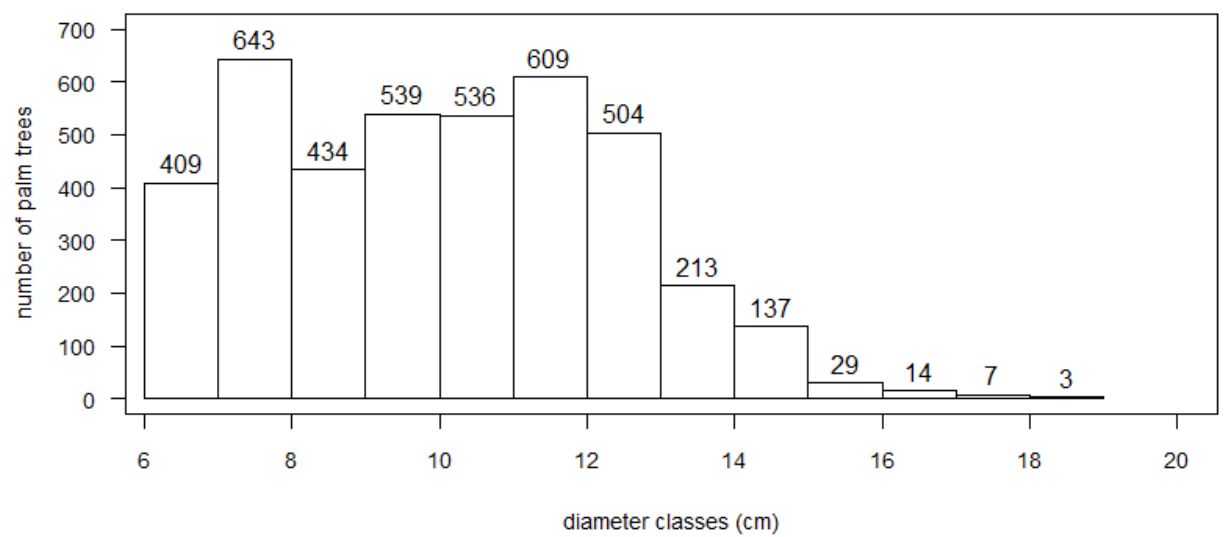

Figure 4. Distribution of the diameter frequencies of the açaí palm tree individuals with $\mathrm{DBH} \geq 6.36 \mathrm{~cm}$.

By the above distribution, a higher quantity of palm trees is observed in the first 7 diametric classes (3,674 palms), that is, a very high quantity ( $90 \%$ of the total) with small diameters, less than or equal to $12 \mathrm{~cm}$ of DBH. From the 8th class onwards, this pattern starts to decline, with a smaller number of palm trees presenting $\mathrm{DBH} \geq 13 \mathrm{~cm}$, approximately $10 \%$ of the total of palm trees. This pattern at the Araguari River is similar to that observed in a floodplain by Santos et al. (2018), whose pattern followed the "inverted J", with most individuals occupying the first two diameter classes.

Height is an important dendrometric variable, especially when it comes to the management of açaí palm tree. In the Araguari valley, the average height of açaí palm trees was $16.19 \mathrm{~m}$, with a maximum found of $38 \mathrm{~m}$ and a minimum of $2 \mathrm{~m}$ (Figure 5).

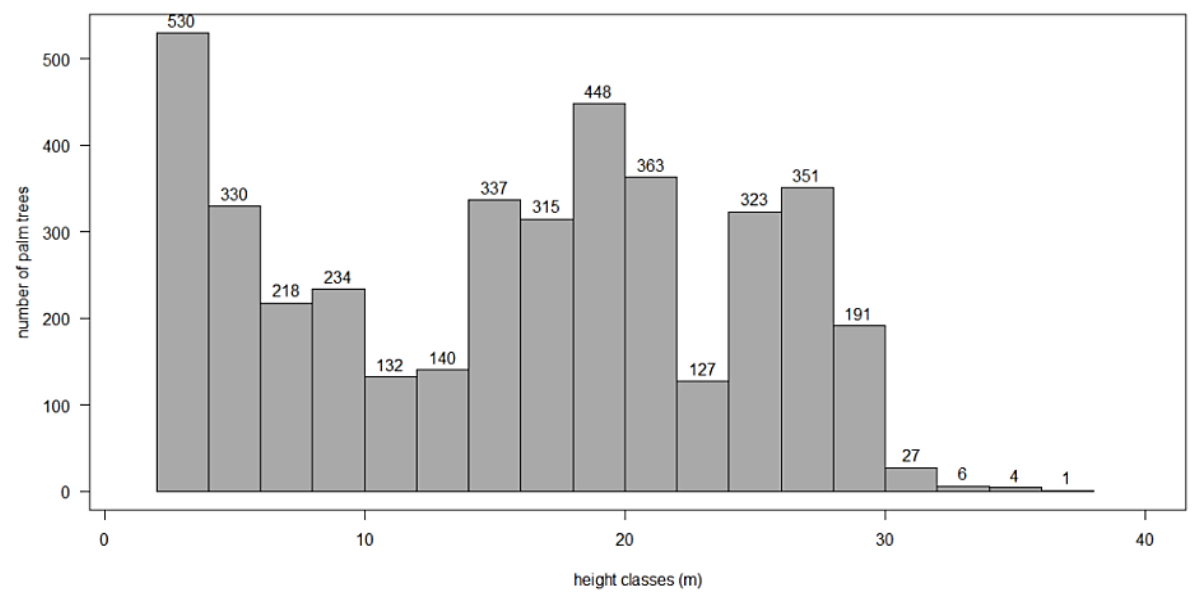

Figure 5. Distribution of the frequencies of heights of the açaí palm tree individuals with $\mathrm{DBH} \geq 6.36 \mathrm{~cm}$.

In the above distribution, from height class 7 onwards, there is a greater number of palm trees (2,493 individuals), i.e., $~ 60 \%$ of the palms occupying the higher strata of the açai areas, with more than $14 \mathrm{~m}$. This finding reflects the status in which these açaí palm areas are found in the Araguari valley, completely wild and without any type of management activity on the part of the their owners. Santos et al. (2018) point out that E. oleracea is a species which grows disorganized in the environment in the presence of light, for example, in the clearings formed by natural falls of large trees within the forest. 
These data suggest the need for intervention in the area (use of açaí management techniques), with their lowering to provide better fruit production results and greater safety during the harvest. Clump thinning is an important management intervention and consists of removing stems that are low in production, sick or too high for the harvest; it decreases the population density of açaí palms and increases the production of fruits (Araújo \& NavegantesAlves, 2015).

\section{Composition of the açai clumps}

The Figure 6 shows the average proportions related to the number of plots sampled with the respective composition of clumps, totaling 1,075 clumps, composed of 2,385 adult palms (in reproductive phase), 1,914 young palms (with potential for reproduction) and 8,247 regenerating individuals.

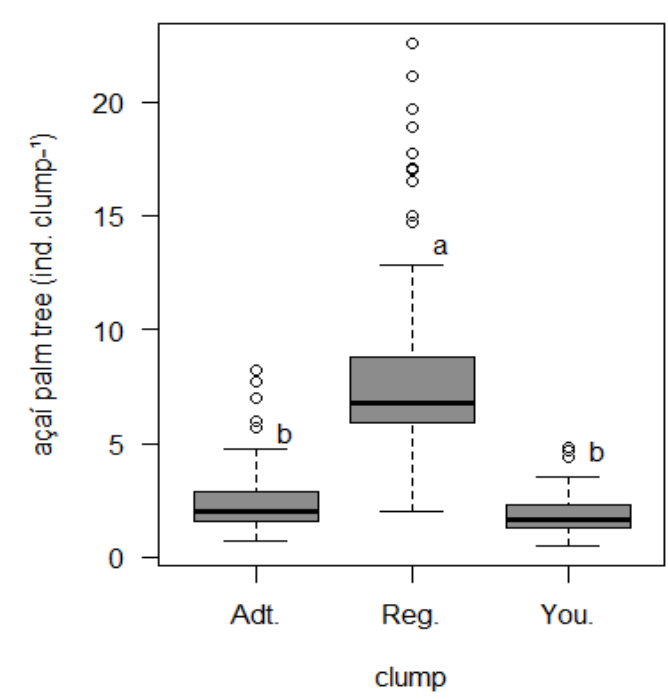

Figure 6. Box plot with average values of palm trees per clump (adult, regenerating and young individuals) in the Araguari Valley. The different letters indicate a significant difference by Kruskal-Wallis test (chi-squared $=162.19, \mathrm{df}=2, \mathrm{p}$-value $<0.05$ ).

In the eastern Amazon, Santos et al. (2018) evaluated 27 ha of floodplain forest and reported that in absolute terms only 370 adult palms per hectare were registered. These figures are well below those found in the Araguari River region (total of 2,385 palms; 1,340 adult palms/hectare).

Regarding natural regeneration, Santos et al. (2018) registered in their study 1,390 new individuals. On the other hand, in the Araguari Valley, this number was significantly higher, accounting for a total of 8,247 regenerants in an area of 1.78 ha.

In a study on the regeneration of E. oleracea, the açaí seedlings with $10 \mathrm{~cm}$ to $2 \mathrm{~m}$ in height, with a survival rate of $(71.3 \%)$ and mortality rate of $(28.7 \%)$ showed a positive correlation between precipitation and observed survival (Freire et al., 2013). In the eastern Amazon, Arévalo-Sandi \& Norris (2018) showed that the success of short-term germination in forests with late and early regrowth is limited by the increased rate of seed removal.

Although the extraction of palm fruits is an interesting alternative, due to the high densities of individuals and productivity/palm, a collection plan cannot fail to consider that both the regeneration of açaí palm trees, as well as the fauna depend on this resource for staying in balance in the environment (Viana et al., 2014).

\section{Açaí fruit production estimates}

Estimated average production of fruit/harvest was 47.7 bags $(50 \mathrm{~kg})$ or $2.39 \mathrm{t}^{\text {harvest }}{ }^{-1}$, considering 1,340 productive palms ha ${ }^{-1}$, with an average of 0.08 cans of fruit per stipe harvest ${ }^{-1}$. 
Average estimate per hectare was 26.8 bags or $1.34 \mathrm{t} \mathrm{ha}^{-1}$ harvest $^{-1}$. The estimated production for the total area (considering the total potential açaí area of 10,600 ha) was 284,080 bags harvest ${ }^{-1}$. Considering the average price of açaí bag $(50 \mathrm{~kg})$ at $\mathrm{R} \$ 136$, a value informed by local producers who sell the fruit during the harvest, the estimated net revenue per hectare/harvest was $R \$ 2,958$, with a monthly average of $\mathrm{R} \$ 438.89$ per harvest.

In a rural community at the Araguari River, Santos et al. (2015) reported that the species most commercialized was açaí, with an estimated average of 2,083 kg year-1. In 2012, the main non-timber forest product extracted in the state of Amapá was açaí (generating $R \$ 2,234$ of income for producers) and the total production was 1,893 tons (Viana et al., 2014).

In a riverside community at the estuary of the Amazon River, the average production per family was 11.9 tons of açaí, while in the 2016 harvest, açaí was sold by producers for $\mathrm{R} \$ 18.57 / \mathrm{can}$. In the off-season, the volume produced was not quantified, since production in this period is very scarce and the harvested production is destined for family consumption (Silva Junior et al., 2019). At the estuary of the Amazon River, the annual fruit production revenue was estimated to be between $R \$ 8,912$ and $R \$ 9,115$ per ha year ${ }^{-1}$ and the total estimated revenue for E. oleracea products was $R \$ 18,464$; about $97 \%$ of this value came from fruit production (Santos et al., 2018).

Azevedo (2010) reported that the combination of three management practices: cleaning the açaí palm area, removal of some palm trees, forest tree thinning (removal of some tree species), allowed riparian people to obtain a fruit yield estimated at $12 \mathrm{t} \mathrm{ha}^{-1}$ year $\mathrm{r}^{-1}$ under more intensive management, which corresponds to three-fold increase over the unmanaged area with an estimated yield of $4 \mathrm{t} \mathrm{ha}^{-1}$ year ${ }^{-1}$.

\section{CONCLUSIONS}

Euterpe oleracea is present throughout the plant physiognomy of the studied area and shows a high abundance of adult, young and regenerating individuals in the lowland forests of the Araguari River. However, the density of 604.5 clumps ha- $^{-1}$ and the high number of stems per clump shows that the açaí palm areas are native and not managed. The low estimate of fruit production of $1.34 \mathrm{t} \mathrm{ha}^{-1}$ leads us to infer that the native açaí palm areas in the Araguari River Valley present low production, although the areas are quite dense. This study represents an unprecedented effort to sample native açaí palm areas in the Araguari Valley and forest research is expected to advance in the region, especially with regard to monitoring the production of fruit and phenology of the species.

\section{ACKNOWLEDGMENTS}

To Research Support Foundation of the state of Amapá (FAPEAP), process related to the Araguari Valley Research Incentive Program, Public Call 004/2017/FAPEAP and pursuant to Memo No. 003/2018 CCT/FAPEAP and Ferreira Gomes Energia S/A. To Instituto Estadual de Florestas do Amapá (IEF/AP) and Instituto de Desenvolvimento Rural do Amapá (RURAP) for their support. To the extractive workers of the middle and lower Araguari River.

\section{REFERENCES}

Almeida, A. F., \& Jardim, M. A. G. (2011). Florística e estrutura da comunidade arbórea de uma floresta de várzea na llha de Sororoca, Ananindeua, Pará, Brasil. Scientia Forestalis, 39(90), 191-198.

Alvares, C. A., Stape, J. L., Sentelhas, P. C., Moraes Gonçalves, J. L., \& Sparovek, G. (2013). Köppen's climate classification map for Brazil. Meteorologische Zeitschrift (Berlin), 22(6), 711-728. http://dx.doi.org/10.1127/0941-2948/2013/0507.

Amsellem-Laufer, M. (2015). Euterpe oleracea Martius (Arecaceae): açaí. Phytothérapie, 13(2), 135-140. http://dx.doi.org/10.1007/s10298-015-0942-2.

Araújo, C. T. D., \& Navegantes-Alves, L. (2015). de F. From extractivism to intensive cultivation of açaí palm (Euterpe oleracea Mart.) in amazon estuary: management systems and their implications on diversity of tree species. Revista Brasileira de Agroecologia, 10(1), 12-23. 
Arévalo-Sandi, A. R., \& Norris, D. (2018). Short term patterns of germination in response to litter clearing and exclosure of large terrestrial vertebrates along an Amazon forest regrowth gradient. Global Ecology and Conservation, 13, e00371. http://dx.doi.org/10.1016/j.gecco.2017.e00371.

Azevedo, J. R. (2010). Sistema de manejo de açaizais nativos praticados por ribeirinhos. São Luis: EDUFMA.

Balslev, H., Bernal, R., \& Fay, M. F. (2016). Palms - emblems of tropical forests. Botanical Journal of the Linnean Society, 182(2), 195-200. http://dx.doi.org/10.1111/boj.12465.

Boaventura, F. M. C., \& Narita, C. (1974). Geomorfologia da Folha NA/NB.22 - Macapá. In Brasil. Departamento Nacional da Produção Mineral. Projeto RADAM. Projeto de Integração Nacional (467 p.). Rio de Janeiro: DNPM.

Brown, M. B., \& Forsythe, A. B. (1974). Robust tests for the equality of variances. Journal of the American Statistical Association, 69(346), 364-367. http://dx.doi.org/10.1080/01621459.1974.10482955.

Campbell, A. J., Carvalheiro, L. G., Maués, M. M., Jaffé, R., Giannini, T. C., Freitas, M. A. B., Coelho, B. W. T., \& Menezes, C. (2018). Anthropogenic disturbance of tropical forests threatens pollination services to açaí palm in the Amazon river delta. Journal of Applied Ecology, 55(4), 1725-1736. http://dx.doi.org/10.1111/1365-2664.13086.

Carvalho, R. C. (2018). Recuperação florestal em açaizais de várzea submetidos ao manejo intensivo no estuário amazônico. (Dissertação de mestrado). Universidade Federal do Pará. Retrieved in 2021, May 12, from http://repositorio.ufpa.br/jspui/handle/2011/10237.

Cappelatti, L., \& Schmitt, J. L. (2015). Spatial distribution and population structure of Palms (Arecaceae) in a forest fragment of lowland dense humid forest in south Brazil. Ciência Florestal, 25(4), 817-825. http://dx.doi.org/10.1590/s1809-98232013000400007.

Cialdella, N., \& Navegantes Alves, L. (2014). La ruée vers l'« açaí » (Euterpe oleracea Mart.): trajectoires d'un fruit emblématique d'Amazonie. Revue Tiers Monde, 4(4), 119. http://dx.doi.org/10.3917/rtm.220.0121.

Conover, W. J. (1971). Practical nonparametric statistics (one-sample Kolmogorov test) (3rd ed.). New York: John Wiley \& Sons.

Cordeiro, V. S. C., Bem, G. F., Costa, C. A., Santos, I. B., Carvalho, L. C. R. M., Ognibene, D. T., Rocha, A. P. M., Carvalho, J. J., Moura, R. S., \& Resende, A. C. (2018). Euterpe oleracea Mart. seed extract protects against renal injury in diabetic and spontaneously hypertensive rats: role of inflammation and oxidative stress. European Journal of Nutrition, 57(2), 817-832. http://dx.doi.org/10.1007/s00394-016-1371-1.

Cruz Junior, F. O. (2016). Caracterização morfológica e da produção de frutos de populações de açaizeiros estabelecidas em Mazagão - Amapá (Dissertação de mestrado). Universidade Federal do Amapá. Retrieved in 2021, May 14, from http://www2.unifap.br/ppgbio/files/2016/08/Dissertação-Franciscode-Oliveira-Cruz-Junior.pdf

Cunha, A. C., Vilhena, J. E. S., Santos, E. S., Saraiva, J. M. B., Kuhn, P. A. F., Brito, D. C., Souza, E. B., Rocha, E. P., Cunha, H. F. A., Brito, A. U., Brasil Júnior, A. C. P., Paca, V. H. M., \& Santos, P. V. C. J. (2014). Evento extremo de chuva-vazão na bacia hidrográfica do rio Araguari. Revista Brasileira de Meteorologia, 29(95), 95-110. http://dx.doi.org/10.1590/0102-778620130051.

Dodge, Y. (2008). Kruskal-Wallis Test. In Y. Dodge (Ed.), The Concise Encyclopedia of Statistics (pp. 288290). New York: Springer. https://doi.org/10.1007/978-0-387-32833-1_216.

Ecotumucumaque. (2013). Plano básico ambiental do aproveitamento hidrelétrico Cachoeira Caldeirão (pp. 1-36). Programas Ambientais, Meio Socioeconômicos.

Eletronorte. (1999). Estudos de inventário hidrelétrico: bacia hidrográfica do rio Araguari no Estado do Amapá: relatório final (118 p.). Macapá.

Ferreira Gomes. Prefeitura Municipal. (2013). Plano diretor participativo do município de Ferreira Gomes, Estado do Amapá: diagnóstico das condicionantes, deficiências e potencialidades municipais propostas e ações. Ferreira Gomes.

Freire, A. S. C., Vitorino, M. I., Jardim, M. A. G., De Sousa, A. M. L., Quaresma, A. C., De Oliveira, F. G., \& Pereira, R. N. (2013). Analysis of the establishment of seedlings of açai (Euterpe oleracea Mart.) in the understory of a forest of Amazon floodplain. Earth Interactions, 17(9), http://dx.doi.org/10.1175/2012EI000448.1.

Freitas, J. D. L., Santos, E. S., Cruz Junior, F. D. O., \& Santos, A. C. (2020). Extractive activity of Euterpe oleracea Mart. (Acai palm tree) in the Araguari River Valley, Eastern Amazon. Journal of Agricultural Studies, 8(2), 110. http://dx.doi.org/10.5296/jas.v8i2.15679. 
Freitas, M. A. B., Vieira, I. C. G., Albernaz, A. L. K. M., Magalhães, J. L. L., \& Lees, A. C. (2015). Floristic impoverishment of Amazonian floodplain forests managed for açaí fruit production. Forest Ecology and Management, 351, 20-27. http://dx.doi.org/10.1016/j.foreco.2015.05.008.

Instituto Brasileiro de Geografia e Estatística - IBGE. (2004). Geomorfologia: base cartográfica do estado do Amapá (275 p.). Rio de Janeiro.

Lau, A. V., \& Jardim, M. A. G. (2013). Florística e estrutura da comunidade arbórea em uma floresta de várzea na Área de Proteção Ambiental, Ilha do Combu, Belém, Pará. Scientia Forestalis, 3(2), 88-93. http://dx.doi.org/10.18561/2179-5746/biotaamazonia.v3n2p88-93.

Maués, B. A. R., Jardim, M. A. G., Batista, F. D. J., David, T., \& Medeiros, S. (2011). Composição florística e estrutura do estrato inferior da floresta de várzea na área de proteção ambiental Ilha do Combu, município de Belém, estado do Pará. Acta Amazonica, 35, 669-677.

Menaa, F. (2014). The Berry Fruit Açai (Euterpe oleracea Mart.): Bringing Health Benefits and Exotism to the Modern Table. Advances in food technology and nutritional sciences, 1(1), 1-4. http://dx.doi.org/10.17140/AFTNSOJ-1-101.

Mendonça, V., \& Del Bianchi, V. (2014). Agronegócio do açaí (Euterpe oleracea Mart.) no município de Pinheiro - MA. Revista SODEBRAS, 9(100), 62-65.

Miranda, D. L. C., Sanquetta, C. R., Costa, L. G. S., \& Corte, A. P. D. (2012). Biomassa e carbono em Euterpe oleracea Mart., na Ilha do Marajó - PA. Floresta e Ambiente, 19(3), 336-343. http://dx.doi.org/10.4322/floram.2012.039.

Oliveira, M. S. P., \& Schwartz, G. (2018). Açaí - Euterpe oleracea. In S. Rodrigues, E. O. Silva \& E. S. Brito (Eds.), Exotic fruits (pp. 1-5). London: Academic Press. https://doi.org/10.1016/b978-0-12-803138-4.00002-2.

Paniagua-Zambrana, N., Bussmann, R. W., \& Macía, M. J. (2017). The socioeconomic context of the use of Euterpe precatoria Mart. and E. oleracea Mart. in Bolivia and Peru. Journal of Ethnobiology and Ethnomedicine, 13(1), 1-17. http://dx.doi.org/10.1186/s13002-017-0160-0.

Quaresma, S. M., \& Cunha, E. B. (2012). Manejo de açaízais, como prá -tica de gestão e educação Ambiental: um estudo de caso da comunidade de franco grande do bailique/amapá. Revista Meio Ambiente e Sustentabilidade, 2(1), 100-120.

Queiroz, J. A. L., \& Machado, S. A. (2008). Fitossociologia em floresta de várzea do estuário amazônico no Estado do Amapá. Pesquisa Florestal Brasileira, (57), 5-20.

Queiroz, J. A. L., Machado, S. A., Hosokawa, R. T., \& Silva, I. C. (2007). Estrutura e dinâmica de floresta de várzea no estuário amazônico no Estado do Amapá. Floresta, 37(3), 339-352. http://dx.doi.org/10.5380/rf.v37i3.9930.

Queiroz, J. A. L., Mochiutti, S., \& Santos, J. A. (2015). Manejo de açaizais de grotas (Comunicado Técnico, No. 140, pp. 1-11). Macapá: Embrapa.

R Development Core Team. (2020). R: a language and environment for statistical computing. Vienna. Retrieved in 2021, May 14, from http://www.r-project.org

Santos, A. C., Freitas, J. L., Silva, R. B. L., Moraes, L. L. C., Matos Filho, J. R., Cruz Junior, F. O., \& Cantuária, P. C. (2015). Caracterização da Atividade Extrativa Vegetal na Comunidade São Tomé, Ferreira Gomes, Amapá, Brasil. Biota Amazônia, 5(4), 42-47. http://dx.doi.org/10.18561/21795746/biotaamazonia.v5n4p42-47.

Santos, B. L. G., Gama, J. R. V., Ribeiro, R. B. da S., Anjos, K. F., Gomes, K. M., Ximenes, L. C., \& Melo, L. O. (2018). Estrutura e valoração de Euterpe oleracea em uma floresta de várzea na Amazônia. Advances in Forestry Science, 5(3), 391-396.

Silva Junior, J. I. S., Rebello, F. K., Lima, H. V., Santos, M. A. S., Santos, P. C., \& Lopes, M. L. B. (2019). Socioeconomics of acai production in rural communities in the Brazilian Amazon: a case study in the municipality of Igarapé-Miri, State of Pará. The Journal of Agricultural Science, 11(5), 215. http://dx.doi.org/10.5539/jas.v11n5p215.

Silva, C. N., Lima, R. Â. P., \& Marinho, V. (2018). Desestruturação territorial na atividade pesqueira : a instalação de usinas hidroelétricas na bacia do Araguari (Ferreira Gomes-AP). Revista NERA, 21(42), 186-201. http://dx.doi.org/10.47946/rnera.v0i42.5692.

Soares, C. P. B., Paula Neto, F., \& Souza, A. L. (2012). Dendrometria e inventário florestal (2. ed., 272 p.). Viçosa: Editora UFV.

Sturges, H. (1926). The choice of a class interval. Journal of the American Statistical Association, 21(153), 65-66. http://dx.doi.org/10.1080/01621459.1926.10502161.

Viana, V., Viana, C., Euler, A., Grieg-Gran, M., \& Bass, S. (2014). Economia Verde no Estado do Amapá, Brasil. London: IIED. 
Wadt, L. H. O., Rigamonte-Azevedo, O. C., Ferreira, E. J. L., \& Cartaxo, C. B. C. (2004). Manejo de açai solteiro (Euterpe precatória Mart.) para produção de frutos (28p.). Rio Branco, AC: Secretaria de Extrativismo e Produção Familiar.

Wittmann, F., Householder, E., Piedade, M. T. F., Assis, R. L., Schöngart, J., Parolin, P., \& Junk, W. J. (2013) Habitat specifity, endemism and the neotropical distribution of Amazonian white-water floodplain trees. Ecography, 36(6), 690-707. http://dx.doi.org/10.1111/j.1600-0587.2012.07723.x.

Wycoff, W., Luo, R., Schauss, A. G., Neal-Kababick, J., Sabaa-Srur, A. U. O., Maia, J. G. S., Tran, K., Richards, K. M., \& Smith, R. E. (2015). Chemical and nutritional analysis of seeds from purple and white açaí (Euterpe oleracea Mart.). Journal of Food Composition and Analysis, 41, 181-187. http://dx.doi.org/10.1016/j.jfca.2015.01.021.

Authors' contributions: ACS: Data curation, formal analysis, investigation, methodology, project adminisitration, visualization, writing - original draft, writing - review \& editing. JLF: Investigation, formal analysis, methodology, Writing - original draft, Writing - review \& editing. FOC): conceptualization, resources, supervision. 